\title{
RELATIVE CLAUSES FROM ENGLISH TO ALBANIAN
}

\author{
Suela Koça ${ }^{1}$, Vasilika Pojani ${ }^{2}$
}

\begin{abstract}
This paper aims to describe the use of relative clauses in English and Albanian by comparing different clause types. Some theoretical issues addressed in this article include the definition of relative clauses, the relativized elements, and the use of relative pronouns and adverbs in both languages. Distinctions and similarities are identified by analyzing the way in which these clauses are translated from English into Albanian. The theoretical part is illustrated by examples extracted from "Animal Farm" by George Orwell and "Pride and Prejudice" by Jane Austin, and their translated versions in Albanian, "Ferma e Kafshëve" and "Krenari dhe Paragjykime".

The issues treated in this article (either theoretical or practical) may be helpful to Albanian students learning English as a second language. By comparing English examples with their Albanian translations these students may understand and contrast several types of clauses to draw similarities and distinctions.
\end{abstract}

UDC Classification: 81’3, DOI: http://dx.doi.org/10.12955/cbup.v4.784

Keywords: relative clauses, comparison, translation, English, Albanian.

\section{Introduction}

This paper describes a modest comparative study on relative clauses in English and Albanian. The study of relative clauses is relevant because of the special features that distinguish these from other dependent clauses in both English and Albanian. To make this study more relevant, we have taken several examples of these types of clauses from English novels and subsequent versions translated into Albanian.

Relative clauses are subordinate clauses that refer to the noun of the main clause, by identifying or adding extra information to the noun (Foley \& Hall, 2003, p. 298). "Periudhë me fjali të varur përcaktore quhet ajo periudhë në të cilën fjalia e varur tregon në përgjithësi një karakteristikë të një sendi apo frymori të shprehur prej një gjymtyre emërore, të shprehur rëndom me emër ose përemër, $\mathrm{i}$ cili është edhe paraprijësi i saj [A relative clause generally characterizes a thing or person that is expressed by a nominal element, randomly a noun or pronoun, which is its antecedent]" (Çeliku et al, 2002, p. 525). The definition is similar in both languages.

A relative clause gives additional information about someone or something referred to in the main clause. For example: "... he was by no means the only partner who could satisfy them..." (Austen, 1994, p. 59). This was translated into Albanian as: “... ai pa dyshim nuk ishte $i$ vetmi që mund t' $i$ kënaqte..." (Austen, 2005, p. 67). Another example is: "“Man is the only creature that consumes without producing" (Orwell, 1946, p. 19). This was translated into Albanian as:

"Njeriu është e vetmja krijesë që konsumon pa prodhuar" (Orwell, 2006, p. 11).

Relative clauses contain within their structure, an anaphoric element whose interpretation is determined by the antecedent. Other types of clauses may contain anaphoric elements, for example, in the sentence: "It was soon noticed that when there was work to be done the cat could never be found. She would vanish for hours on end..." (Orwell, 1946, p. 37). The same in Albanian is: "Edhe sjellja e maces dukej disi e çuditshme - shpejt $u$ vu re se sa herë dilte ndonjë punë për të bërë ajo s'gjendej kurrkund" (Orwell, 2006, p. 29). The reference to "she [ajo]" in the second part of the clause is related to the "cat [maces]", which is in the first part of the clause. In this example, however, the anaphoric relation is incidental in that there is coordination between the two parts of the sentences. This coordination does not mean that every other coordinating clause must contain such a relation. However, in relative clauses, such an anaphoric relation is an essential feature. The element that distinguishes relative clauses from other types of subordinate clauses is the specific nature of the anaphoric relation involved (Huddleston, 1984, p. 274). The antecedent is typically the head that the

\footnotetext{
${ }^{1}$ Suela Koça Department of Foreign Languages, University “F. S. Noli”, Korçë, Albania, spicikoca@gmail.com

${ }^{2}$ Vasilika Pojani Department of Foreign Languages, University “F. S. Noli”, Korçë, Albania, vpojani@ yahoo.com
} 
clause modifies, and the anaphoric element itself has distinct properties. So, "wh-" words, as in relative pronouns, such as "who and which [i cili, e cila]", are distinct from the anaphoric forms that are used in main clauses; these are synonymous with interrogative words, though the latter are not anaphoric. For other relatives, the anaphoric element comprises a gap, though distinct from other anaphoric gaps with respect to position and interpretation. The same phenomenon occurs in Albanian.

\section{Methods}

\section{What can be relativised?}

The essential anaphoric element in a relative clause is called the relativized element. In respect of this element, it is important that the form of the relative clause differs from that of a main clause.

Subject

"First came the three dogs, ... then the pigs, who settled down in the straw immediately in front of the platform" (Orwell, 1946, p. 16). This was translated into Albanian as: "Të parët mbërritën tre qentë, ... fill pas tyre derrat, që zunë vend përpara, ngjitur me platformën" (Orwell, 2006, p.8). "The three hens who had been the ringleaders in the attempted rebellion over the egg now came forward ..." (Orwell, 1946, p. 83). This was translated into Albanian as: "Përpara dolën ato tri pulat që njiheshin si udhëheqëse të përpjekjes për rebelim lidhur me çështjen e vezëve" (Orwell, 2006, p. 73).

Object

"When Boxer heard this he fetched the small straw hat which he wore in summer..." (Orwell, 1946, p. 30). This was translated into Albanian as: "Me të dëgjuar këtë, Bokseri kapi kapelen e kashtës që mbante për t'u mbrojtur..." (Orwell, 2006, p. 22).

Relativization applies to direct objects in both languages, but not normally to indirect ones, especially in English. In Albanian they are more common, as in the following example: "Të tre këta i përpunuan mësimet e majorit në një system të plotë të mendimit teorik, të cilit i dhanë emrin Animalizëm" (Orwell, 2006, p. 18). In English this reads as: "These three had elaborated old Major's teachings into a complete system of thought, to which they gave the name of Animalism" (Orwell, 1946, p. 26). Often, in English, we find indirect objects that are relativized using the preposition "to".

Predicative complement

Relativisation of predicatives is comparatively rare, and almost entirely limited to the subjective type in both languages, especially in Albanian, where the relative pronoun should not be omitted. In this study, no examples were found in either language.

\section{Complement of preposition}

" ... the nose-rings, the dog-chains, the cruel knives with which Mr. Jones had been used to castrate the pigs and..." (Orwell, 1946, p. 29). This was translated into Albanian as: “...zinxhirët e qenve dhe thikat mizore me të cilat zoti Xhons masakronte derrat dhe qengjat" (Orwell, 2006, p. 21). "...those ribbons that you are so devoted to are the badge of slavery" (Orwell, 1946, p. 27). This was translated into Albanian as: "Këto kordele që ti i ke kaq për zemër janë symbol i skllavërisë" (Orwell, 2006, p. $18)$.

In Albanian "që [that]" is not used with a preposition, either preceding or following it. However, the relative pronoun "i cili [which]" can be used with a preposition that precedes it, but not with a preposition following it, as in the English language.

As Huddleston (2002) wrote, with relative pronouns starting with "wh", the preposition may be adjoined by its complement, for example: "the cruel knives with which Mr. Jones had been used to castrate the pigs", which translates into Albanian as "thikat mizore me të cilat zoti Xhons masakronte derrat dhe qengjat". In the Albanian language, this is the only accepted way of using a preposition with these relatives.

Adjuncts and associated complements

"There were days when they felt they would sooner have had less figures and more food" (Orwell, 1946, p. 89). This was translated into Albanian as: "Thuhej-ç'thuhej, kishte ditë kur atyre u dukej se do të parapëlqenin të konsumonin më pak shifra dhe më shumë ushqim” (Orwell, 2006, p. 78). “...to find some place where they would not be trodden on" (Orwell, 1946, p. 17). This was translated into 
Albanian as: "Të shqetësuara, kërkonin një vend ku të mos i shkelnin" (Orwell, 2006, p. 9). A case of this kind is to be distinguished from that mentioned under the previous sub-heading. Here it is the whole adjunct or complement that is relativized, whereas in the above example relativization involves only the NP functioning as a complement within the PP. The above case has broader application because it can apply the full range of prepositions (Huddleston \& Pullum, 2002, p. 1045). These constructions are similar in Albanian, except that in Albanian the relative pronoun (or adverb) is not omitted.

\section{Genitive subject-determiner}

"Nothing could have been achieved without Boxer, whose strength seemed equal to that of all the rest..." (Orwell, 1946, p. 64). This was translated into Albanian as: "Po të mos kishte qënë Bokseri, me siguri nuk do të kishin arritur asnjë rezultat. Dukej sikur ai kishte forcë sa për të gjithë të tjerët..." (Orwell, 2006, p. 54). (forca e të cilit). "There had also been a very strange custom, whose origin was unknown..." (Orwell, 1946, p. 127). This was translated into Albanian as: Ka ekzistuar edhe një rit i keq, të cilit nuk i dihet as origjina..." (Orwell, 2006, p. 115). (origjina e të cilit). The above examples show that the author of the Albanian text had not translated these constructions in the same way as they are used in the English language. In the first example, the author had used two different clauses to express the same idea, while in the other, "të cilit [ ]" has the function of an indirect object and not of a genitive.

The contrast between personal "who" and non-personal "which" is neutralized in the genitive, where "whose [i të cilit...]" is the only form of relative pronoun. The use of "whose" occurs with both personal and non-personal antecedents. In Albanian, this form can vary with antecedent, number, and gender. The position is also different in Albanian as, unlike its English equivalent, it does not immediately follow the antecedent. Nonetheless, "whose" can be found in constructions with prepositions, such as "of" or "from". Such examples in the prose studied were rare and characteristic of the written prose. The following examples are taken from literary works. "He had entertained hopes of being admitted to a sight of the young ladies, of whose beauty he had heard much" (Austen, 1994, p. 5). This was translated into Albanian as: "Ai kishte shpresë të fitonte respektin e zonjushave, për bukurinë e të cilave ai kishte dëgjuar të flitej shumë” (Austen, 2005, p. 9). “... cried Snowball, from whose wounds the blood was still dripping" (Orwell, 1946, p. 49). This was translated into Albanian as: “... thirri Snoubolli, plagët e të cilit ende kullonin gjak" (Orwell, 2006, p. 39). (nga plagët e të cilit). In Albanian the constructions with prepositions are also used and are common, although the second preposition example is translated as a genitive.

\section{Relative pronouns}

In English "that [q]̈]" is the most common relative pronoun ${ }^{3}$. In some specific cases, it might be omissible, but with constraints. In Albanian, it is also common, being appropriate for different genres of the standard language, its omission is impossible. There are no constructions where "that [që]" needs to be absent (with the rather marginal exception of some examples). It is normally possible to add "that [që]" to any relative to obtain a "that" grammatical relative. However, the converse does not hold true. Under certain limited conditions, "that [që]" cannot be omitted from a relative without grammatical loss (Huddleston \& Pullum, 2002, p. 1055). By comparing different examples of English and Albanian we can show the problem with omitting "që [that]" in the Albanian prose.

The relative pronoun, "that [që]", cannot normally be omitted without grammatical error when the relativized element is the subject of the relative clause, for example: "... you have heard about the strange dream that I had last night" (Orwell, 1946, p. 17), where "that" acts as the object and not the subject of the relative clause. This was translated into Albanian as: “... duhet të keni dëgjuar për punën e asaj ëndrrës së çuditshme që pashë mbrëmë” (Orwell, 2006, p. 9). In another: “... you have heard about the strange dream (that) I had last night". This translates into Albanian as: “... duhet të keni dëgjuar për punën e asaj ëndrrës së çuditshme (që) pashë mbrëmë’.

"Man* is the only creature that consumes without producing" (Orwell, 1946, p. 19), where "that" acts as the subject of the relative clause and *in this example, "man" is a collective (and outdated) term for

\footnotetext{
${ }^{3}$ Some generativists consider that as a subordinating conjuction and not a relative pronoun.
} 
"a human being", rather than the male gender. This was translated into Albanian as: "Njeriu është e vetmja krijesë që konsumon pa prodhuar" (Orwell, 2006, p. 11). Compare this with this example: "Man* is the only creature consumes without producing", which is translated into Albanian as: Njeriu është e vetmja krijesë konsumon pa prodhuar.

The relative pronoun "that [që]" can be omitted from the first sentence without grammatical loss because it is an object. However, any other non-subject would similarly allow omission of "that [që]", for example: "He's not the man (that) he was a few years ago" (predicative complement); Ai nuk është burri (që) ishte para disa vitesh [I can't find the book (that) you asked for] (complement of preposition); and Unë nuk mund t'a gjej librin (që) ti kërkove.

Some written versions of English do allow "that [që]" to be omitted from clauses with relativized subjects under certain conditions, for example: "It was my father (_did most of the talking)", translated into Albanian as: "Ishte im atë (_ foli më shumë)". Such cases are clearly non-standard (Huddleston \& Pullum, 2002, p. 1055), and in Albanian are not used.

The use of "that [që]" is not omissible in supplementary relatives. ${ }^{4}$ Although supplementary relatives are normally of the relative pronouns starting with "wh", examples with "that [që]" are also relevant. However, no examples were found in this study. In Albanian, the same issue occurs, in that "që [that]" is found in supplementary clauses, and cannot be omitted. For example: "Mes për mes hundës i kalonte një pullë e bardhë, që i jepte fytyrës së tij pamjen e një budallai..." (Orwell, 2006, p. 8), which in English reads as "A white stripe down his nose gave him a somewhat stupid appearance..." (Orwell, 1946, p. 16). According to Huddleston \& Pullum (2002, p. 1056), in contexts other than the above, "that [që]" is grammatically optional. It is somewhat likely to be omitted in informal rather than formal style, and when the antecedent and the relative clause, or at least its subject, are both short.

Clauses without wh do not contain relative phrases, and as a result there are no corresponding forms corresponding with those with wh, as in the following example: "This morning I saw you looking over the hedge that divides Animal Farm from Foxwood" (Orwell, 1946, p. 51). This was translated into Albanian as: "Të pashë sot në mëngjes kur po rrije ngjitur me gardhin që ndan Fermën e Kafshëve nga Foksudi" (Orwell, 2006, p. 41).

In Albanian, only the first version with "që [that]" is acceptable, while other constructions with the "që [that]" in the genitive or with a preposition are not used.

Other relative pronouns in English involve "who" and its variants, "whose", "whom", and "which". In Albanian, the relative pronouns are "i cili" and "e cila" and their variants, "të cilët" and "e të cilëve", according to number and gender.

The relative pronoun, "which [i cili]", belongs to two categories: pronoun and determiner. The latter is found only in nonrestrictive clauses. As a pronoun, it contrasts in gender with "who [i cili]", as a nonpersonal type compared to that of personal. The choice of one or the other is determined by the nature of the antecedent. The distinction between "who" and "which" is very similar, but not identical to the one between "he [ai]" and "she [ai and ajo]" on the one hand, and "it [për sende]" on the other. In Albanian, there is no distinction between personal and non-personal. The relative pronoun, " $\mathrm{i}$ cili", changes its form, depending on the gender, number, and case of the antecedent. It also changes when it is used with a preposition. In this way, it expresses its relation with the antecedent not only semantically but also syntactically.

The relative pronoun, "who", occurs predominantly with human antecedents, but can occur with antecedents denoting animals. Both "which" and "who" are applicable and "who" is by no means uncommon. Using "who" conveys a greater degree of empathy or personal interest and involvement than using "which". In the novel "Animal Farm", there are many examples of animals as the head of a noun phrase, with the point of the author being to depict these as human characters. The most obvious cases where "who" is used in this respect refer to pets, but also for other creatures (or collection of creatures; Huddleston \& Pullum, 2002, p. 1048), as in the following examples: "At the last moment Mollie, the foolish, pretty white mare who drew Mr. Jones's trap, came mincing daintily in, chewing at

\footnotetext{
4 "Supplementary" is the term used by Huddleston (2002, p. 1056) to refer to the traditional "Non-restrictive" or "Nondefining" relatives.
} 
a lump of sugar" (Orwell, 1946, p. 17). In Albanian this reads as: "Në fund, duke u spërdredhur me një petë sheqeri në gojë, hyri Moli, pela bukuroshe e trushkulur, që tërhiqte dyrrotëshin e zotit Xhons" (Orwell, 2006, p. 9). Then there is "Pre-eminent among the pigs were two young boars named Snowball and Napoleon, whom Mr. Jones was breeding up for sale" (Orwell, 1946, p. 25). In Albanian this is: "Midis derrave u shquan si dy veprimtarë dy meshkuj të rinj të quajtur Snouboll dhe Napolon, të cilët zoti Xhons po i majmte për t'i shitur" (Orwell, 2006, p. 17).

In Albanian, there is no such division between "who" and "which" because, as we previously mentioned, the relative pronoun " $\mathrm{i}$ cili [which]" is common with personal, non-personal, and animal antecedents. In English, there are two special uses of "which [i cili]" with human antecedents, namely, as a predicative complement of "be [jam]" and as a complement of "have [kam]". When the antecedent is a coordination of nouns differing with respect to the use of personal rather than the nonpersonal, the conflict is typically resolved by means of proximity, with the gender of the pronoun determined by the last noun in the coordination (Huddleston \& Pullum, 2002, p. 1049). In Albanian, as there is only one pronoun used, the pronoun form is determined by the last noun (if the noun is in singular or plural tense and masculine or feminine gender).

The conflict can also be avoided by using other relative pronouns, for example "that [që]". This is applicable in both languages. "There were only four dissentients, the three dogs and the cat, who (that) was afterwards discovered to have voted on both sides" (Orwell, 1946, p. 21). This was translated into Albanian as: "Pati vetëm katër vota kundër, tre qentë dhe macja, e cila, (që) siç u zbulua më pas, kishte votuar në të dy krahët" (Orwell, 2006, p. 13). There has always been confusion regarding the use of which or that with relative clauses (Quinion, 1996). This confusion is not surprising because, since the last century, there have been changes in the use of relative clauses. This usage is closely related with the distinction that grammarians make between (restrictive) and (non-restrictive) relative clauses.

Historic books usually introduce two main issues for the distinction between these relative clauses, namely, that restrictive relatives are introduced by "that [që]" and are not preceded by punctuation. Non-restrictive relatives are introduced by "which [i cili, e cila]" and should be marked off by punctuation. Few authors had systematically applied this rule in the works that we studied, which included many examples with "which [i cili, e cila]" introducing a restrictive relative clause, for example: "He seized the gun which always stood in a corner of his bedroom ... (Orwell, 1946, p. 24"). This was translated into Albanian as: "Rrëmbeu çiften që e mbante gjithmonë në qoshe të dhomës së gjumit..." (Orwell, 2006, p. 16). "It is, in short, impossible for us to conjecture the causes or circumstances which may have alienated them..." (Orwell, 1946, p. 58). This was translated into Albanian as: "Prandaj e kemi të pamundur të kuptojmë shkaqet apo rrethanat që i kanë bërë të huaj..." (Orwell, 2006, p. 66). The 1965 edition of Fowler's Modern English Usage stresses that if all writers agreed to use "that" as the restrictive relative pronoun and "which" as non-restrictive, the writing would read clearer and precise. This principle is still followed, but possibly it is not followed by all or even the best writers. Despite the stylistic distinction, there are some situations where "that" is preferable to "which" (Quinion, 1996). The following are examples, although these are not a full list, but moreover tendencies and rules.

- In clauses that follow constructions, "that" is more common: "It is about this that I wish to speak to you (Orwell, 1946, p. 18). This was translated into Albanian as: "Për këtë e ndiej veten më të aftë se çdo gjë, ndaj dhe dua t'ua shpjegoj ju" (Orwell, 2006, p. 10). These are called cleft-constructions. In Albanian, "që [that)" is also more common than "i cili [which]", in these kind of clauses. However, this does not mean that there are no other relative pronouns with these constructions, for example: "... for it was Snowball who was best at writing" (Orwell, 1946, p. 32). This was translated into Albanian as: "Aty Snoubolli i cili ia thoshte më shumë se të tjerët për shkrim e këndim...” (Orwell, 2006, p. 24).

- Clauses referring to words as "anything [ndonjë gjë]", "nothing [asgjë]", "something [diçka]", "everything [gjithçka]", or "all [gjithë]" prefer "that [që]" to "which [i cili]", for example: "But it reminded me of something that I had long forgotten" (Orwell, 1946, p. 22), which in Albanian is: "Por ajo më kujtoi diçka që e kisha harruar prej kohësh" (Orwell, 2006, p. 14).

Nonetheless, we can still find clauses such as the following: "That is something which does not seem to have been factored into the BOJ's thinking" (Japanese Interest Rates, 2007, p. 83), which in 
Albanian reads as: "Kjo është diçka e cila (që) nuk duket të ketë ndikuar në gjykimin e BOJ-së", where "which" (e cila) is used, but in Albanian it sounds better with "që" (that).

In Albanian, the relative pronoun can be omitted when its antecedent is one of the above words. This is a very special case in Albanian because the relative pronoun is almost never removed. For example: "Pasi shëtitën cep më cep, delegacionet shprehën admirimin për gjithçka panë, veçanërisht për mullirin" (Orwell, 2006, p. 111), which in English reads: "They were shown all over the farm, and expressed great admiration for everything they saw, especially the windmill" (Orwell, 1946, p. 124). Clauses that follow an adjective in the superlative degree also have the tendency to prefer "that [që]", for example: "Moreover, it was the biggest harvest that the farm had ever seen" (Orwell, 1946, p. 36). This was translated into Albanian as: "Për më tepër kjo ishte e korra më e bollshme që kishte parë ndonjëherë ferma" (Orwell, 2006, p. 28). It seems that the above tendencies of English do work for Albanian, as shown by the carefully compared examples. In English, this preference involves stress and rhythm. The relative pronoun, "that" contains "soft" syllables and is not usually stressed, while "which" contains a more "tough" initial sound and is easier to stress. Different writers (Lica, 1998) have noticed "that" as having the tendency to occur more often in the spoken register, probably because it can form the contracted "that's", whereas "which" cannot be used in this way. Although "which" can replace "that" in restrictive relatives, "that" should not replace "which" in non-restrictive relatives. Furthermore, we should not change the rules relating to punctuation in this context. The idea is that punctuation is more important here than the choice of the pronoun in similar situations.

\section{Relative adverbs}

When relatives function as adjuncts, they are introduced by relative adverbs, which have the function of mentioning the antecedent made possible by their meanings. Like the relative pronouns, they are syntactic elements of the subordinate clause, according to their function in the proper phrases. In English, the relative adverbs are "where", "when", and "why", but there are also more complex adverbs, such as "where" with a preceding preposition. In Albanian, there are corresponding adverb forms: "ku [where]", "kur [when]", and "përse [why]", but also "si [how]". Example English writings and their Albanian translations were found for the following adverbs:

Where [ku]:

- "Elizabeth ...attended her in the drawing-room; where she was welcomed by her two friends with many professions of pleasure..." (Austen, 1994, p. 36). This was translated into Albanian as: “...Elizabeta...e ndihu të zbriste në dhomën e ndënjjes, $\underline{\mathrm{ku}}$ e mirëpritën dy shoqet e saj, duke i shprehur kënaqësinë e tyre të madhe...” (Austen, 2005, p. 43).

- "...and led him around to the end of the big barn, where the Seven Commandments were written" (Orwell, 1946, p. 123). This was translated into Albanian as: “...dhe e çoi deri në fund të plevicës së madhe ku ishin shkruar Shtatë Urdhrat" (Orwell, 2006, p. 110).

"... these two disagreed at every point where disagreement was possible" (Orwell, 1946, p. 53). This was translated into Albanian as: "Që të dy e kundërshtonin njëri-tjetrin sa herë u jepej rasti" (Orwell, 2006, p. 42). This example shows that not all relatives containing "where" are translated as "ku" in Albanian.

- “...a mysterious country called Sugarcandy Mountain, to which all animals went when they died" (Orwell, 1946, p. 27). This was translated into Albanian as: “...një vend i quajtur "Mali i Bonboneve" ku ishin të destinuar të shkonin pas vdekjes të gjitha kafshët" (Orwell, 2006, p. 19).

When [kur]:

- "Then there came a moment when the first shock had worn off..." (Orwell, 1946, p. 122). This was translated into Albanian as: "Pastaj erdhi një çast kur e morrën veten nga goditja..." (Orwell, 2006, p. 110).

- "Finally there came a night when the gale was so violent that..." (Orwell, 1946, p. 71). This was translated into Albanian as: "Pastaj, një natë, shpërtheu një stuhi kaq e fortë, sa u duk sikur..." (Orwell, 2006, p. 61). This examples shows that not all the relatives are used in the same way in both languages. 
- “...as she had protected the lost brood of ducklings with her foreleg on the night of Major's speech" (Orwell, 1946, p. 85). This was translated into Albanian as: "...ashtu siç kishte mbrojtur edhe ajo vetë me këmbën a saj të pasme atë natë kur fliste Majori” (Orwell, 2006, p. 75).

Why [përse]:

The conjunction, "why", is used only with one noun as its antecedent. However, in this study, we could not find an example. In Albanian, the noun "mënyra" can be used as an antecedent in an expression in which it is completed, for example: "Mënyra (se) si folën për mbrëmjen e Meritonit, qe jashtëzakonisht e veçantë" (Austen, 1994, p. 15), which in English is: "The manner in which they spoke of the Meryton assembly was sufficiently characteristic" (Austen, 2005, p. 10). In this example, the English alternative to "mënyra", i.e. manner, is more naturally followed by an expression that completes it.

\section{Conclusion}

In both English and Albanian, relative clauses are of a special nature in comparison with other subordinate clauses. By providing examples in both English and Albanian, we identified many cases that were similar and several that were different between the languages. We compared an original work in English with its translated variant in Albanian to assess whether the relative clauses in English were translated in the same way in Albanian. Several relative clauses in English did not translate the same into Albanian and thus showed the differences that can exist. This modest paper may be helpful for students of English as a foreign language and translators, especially those who are beginners.

\section{References}

Austen, J. (1994). Pride and Prejudice. Chancellor Press.

Austen, J. (2005). Krenari dhe Paragjykime. Tiranë: Shtëpia Botuese Uegen.

Çeliku, M., Domi, M., Floqi, S., Mansaku, S., Përnaska, R., Prifti, S., Totoni, M. (2002). Gramatika e gjuhës shqipe, Sintaksa [Albanian Language Grammar, Syntax]. Tiranë: Botim i Akademisë së Shkencave.

Foley, M., Hall, D. (2003). Advanced Learner's Grammar Pearson Education Limited.

Huddleston, R. (1984). Introduction to the Grammar of English. Cambridge: Cambridge University Press.

Huddleston, R., Pullum, K. G. (2002). The Cambridge Grammar of the English Language. Cambridge: Cambridge University Press.

Japanese Interest Rates. (2007, January 20). [Taking the hint. The bank of Japan does as it is told and sits tight]. The Economist, 83.

Lica, L. (1998). The Distinction between 'Which' and 'That'. Retrieved from home.earthlink.net/ 1lica/whichthat.htm

Orwell, G. (1946). Animal Farm. New York: Harcourt Brace Jovanovich, INC.

Orwell, G. (2006). Ferma e Kafshëve. Tiranë: Shtëpia Botuese Onufri.

Quinion, M. (1996). World Wide Words: Which versus that. Retrieved from www.worldwidewords.org/articles/which.htm 